\title{
ВОЛИНЬ В ДОБУ УКРАЇНСЬКОЇ ЦЕНТРАЛЬНОЇ РАДИ: ВІЙСЬКОВО-ПОЛІТИЧНІ АСПЕКТИ
}

Аналізуються військово-політичні особливості розвитку Волинської губернії в добу Української Центральної Ради, зокрема, складові державотворчого процесу на місцевому рівні, включаючи формування місцевих органів влади, боротьбу за вплив на волинське населення, діяльність різних політичних сил і військових формувань. У дослідженні характеризуються новостворені військові комітети, ради робітничих і солдатських депутатів, а також події, які суттєво впливали на військово-політичний розвиток волинських земель.

Ключові слова: Українська революція, Волинська губернія, Українська Центральна Рада, військово-політична ситуація, військові комітети, українське військо.

Постановка проблеми та ї̈ актуальність. Столітній ювілей революційних подій, які мали місце на території українських, у тому числі й волинських, земель привернув увагу дослідників вітчизняної минувшини до детального вивчення окремих сторінок Української революції 1917-1921 рр., відкриття й публікацію невідомих досі документів тієї доби, переосмислення висновків, які зробили попередні дослідники. У розрізі зазначеного вище збільшилася кількість публікацій краєзнавчого характеру, де вивчаються особливості різних аспектів революційних процесів, які протікали на конкретній території сучасної України.

Щодо волинського терену, то події столітньої давнини мали свої особливості, викликані, насамперед, довготривалим перебуванням тут військових різних держав. Принагідно вкажемо на те, що активні бойові дії на території західних повітів Волинської губернії тривали від 1915 р. й на початок Української революції Ковельський, Володимир-Волинський і частково Луцький повіти були окуповані австро-угорським й німецьким військовим контингентом.

Отож руйнація політичної системи Російської імперії на території Волинської губернії від лютого 1917 р. мала низку

Дем'янюк Олександр Йосипович - доктор історичних наук, професор, проректор з науково-педагогічної роботи та моніторингу якості освіти Волинського інституту післядипломної педагогічної освіти, м. Луцьк.

(C) Дем'янюк О. Й., 2018 
особливостей, адже місцеве населення активно залучалося до революційних процесів під впливом військовослужбовців російської імператорської армії.

Аналіз попередніх досліджень $i$ публікацій. Новітня незалежність України стала періодом об'єктивного висвітлення маловивчених чи сфальсифікованих сторінок вітчизняної історії. Так до вивчення подій Української революції долучилася ціла низка науковців. Їхні праці окреслили загальну парадигму тих революційних подій. У цих дослідженнях державотворчий процес 1917-1921 рр. розглядався в цілому, без детального аналізу ситуації в окремих регіонах. На регіональному рівні авторами окремих публікацій були: О. Власюк, І. Гуцалюк, О. Дем'янюк, М. Костриця.

Мета та завдання дослідження. 3 огляду на стан наукової розробки означеної проблеми, спробуємо з'ясувати військовополітичні аспекти перебігу Української революції на території Волинської губернії в добу УЦР, з'ясувати вплив революційних подій на життя пересічних волинян, залучення їх військовополітичних процесів.

Виклад основного матеріалу дослідження. Події, що відбулися в лютому 1917 р. у російській столиці, не відразу знайшли підтримку в регіонах. I причини тут не лише у незадовільному рівні свідомості жителів периферії, але й низькому рівні поширення інформації. Так лише вранці 3 березня київська громадська преса видрукувала повідомлення про повалення самодержавства та перехід влади до Тимчасового комітету Державної думи.

У повітових і волосних центрах українських губерній інформація про революцію в Росії поширилася впродовж найближчого тижня. Паралельно тут проходив процес ліквідації царської адміністрації та формувався апарат губернських і повітових комісарів під орудою Тимчасового уряду Росії. Так Волинським губернським комісаром в Житомирі став уродженець Волині кадет А. В'язлов.

Відтак, 6 квітня 1917 р. у Києві розпочав роботу Всеукраїнський національний конгрес, метою якого була консолідація українського руху та визначення найближчих пріоритетів політичної діяльності. На цьому форумі відбувся процес конституціювання УЦР. За повноваженнями ця державна інституція набувала статусу представницького органу влади українського народу. Від Волині до складу УЦР було обрано О. Головка, П. Колесника, Н. Касяненка, 
Б. Козубського [1, с. 1]. Пізніше від Волинської губернії до складу УЦР увійшли: М. Кухаренко, С. Дмиш, С. Підгірський, П. Драчук [2, с. 173].

Щодо більшості волинських земель, то вони не були однорідними ні щодо державної приналежності (вище про це вже згадувалося), ні щодо ставлення до владної вертикалі - Тимчасовий уряд Росії / Українська Центральна Рада. Прифронтовими територіями Волинського краю, що перебували під владою Росії, були: Рівненський, Дубенський, Кременецький та частина Луцького повітів. Тогочас межі фронту проходили по лінії Кисилин Затурці - Локачі - Свинюхи - Горохів - Броди [3, с. 37].

Тут $з$ перших днів зміни політичного режиму держави активізувалася робота партійних, культурних, освітніх, національних організацій. Серед них: громада Товариства українських поступовців, «Селянська спілка», філія українського військового клубу ім. П. Полуботка. У Луцьку було засновано товариство «Українська громада», до якого увійшли здебільшого українці - вояки російської армії. Народний рух поступово набув організованих рис і чіткого національно-державного спрямування, демонструючи зрушення в українському суспільному житті в регіонах. На підтримку діяльності української влади українськими містами пройшли військові паради і маніфестації робітників, солдатів: 11 березня у Проскурові, Козятині, Староконстянтинові, 17 березня - у Білій Церкві, Василькові, Житомирі.

Місцеві органи влади намагалися стати організаційним центром суспільних змін на місцях. У них концентрувалися представники найпотужніших місцевих політичних і громадських сил. I саме тут невдовзі розгорнулася найбільша робота 3 підпорядкування собі місцевих органів влади політичними силами Української Центральної Ради, Тимчасового уряду Росії та російської більшовицької партії. До політичної боротьби почали долучатися Ради робітничих і солдатських депутатів, куди навесні 1917 р. входили, здебільшого, меншовики, есери та бундівці. Однак реальною політичною силою ради стали влітку 1917 р., коли більшість їх складу стало більшовицькими.

Щодо військової палітри Волинської губернії, то тут продовжували перебувати підрозділи російського ПівденноЗахідного фронту: Осібна, 11, 7, 8- ма армії. Станом на 1 квітня 1917 р. в частинах Південно-Західного фронту нараховувалось 
2315,1 тис. солдатів і офіцерів [4, арк. 90], третина 3 яких були українцями. На території Волинської губернії перебувало 11 гарнізонів, загальною чисельністю 65,5 тис. осіб [5].

Зазначимо, що командування російської армії в березні поточного року ще не визначилося зі своєю роллю в нововиявлених політичних обставинах. Так, штаб головнокомандувача ПівденноЗахідного фронту генерала О. Брусилова повідомляв, що «армія виконає свій обов'язок перед рідним краєм» [6, с. $62-63]$, чітко не зазначаючи, яку 3 політичних сил підтримає колишнє імперське військо.

7 березня в губернському місті замість жандармського управління створено міліцію [7, с.95]. 9 березня тут відбулася демонстрація, в якій взяли участь офіцери та солдати місцевого гарнізону, учні початкових та середніх навчальних закладів, громадяни міста [8, с. 72].

8 березня 1917 р. Луцьку міську раду було перейменовано у громадську раду, збільшивши іï кількість 325 до 40 членів шляхом довиборів [9, арк. 1]. 17 квітня збори уповноважених таємним голосуванням обрали 12 членів громадської ради. Через 10 днів після виборів луцький міський голова підполковник В. Малявчик зняв 3 себе повноваження мера та передав їх бухгалтеру А. Варковицькому.

Навесні 1917 р. на території Волинської губернії розпочалося створення рад різноманітних гатунків та політичних забарвлень. На прифронтових волинських територіях почали діяти ради солдатських депутатів і солдатські комітети. Так лише впродовж березня-квітня 1917 р. в містах Волинської губернії утворилося близько 60 відповідних структур. Майже у всіх великих гарнізонах у березні-квітні 1917 р. були створені ради солдатських депутатів, що виглядає цілком логічним явищем 3 огляду на те, що лише в Луцькому гарнізоні перебувало понад 20 тис. військовослужбовців [10, с. 103].

21 березня ради солдатських і офіцерських депутатів запрацювали в Житомирі, Староконстянтинові, Шепетівці. Дещо пізніше вони почали діяти лише у Луцьку (11 липня) та в Рожищах (15 липня) [11, с. 30]. У березні-квітні 1917 р. ради робітничих i солдатських депутатів були утворені в Рівному, Дубно, Острозі, Коростені [12, с. 69].

Паралельно до створення рад розгортався український національний руху в підрозділах російської армії. Там почали 
організовуватися українські ротні громади, до складу яких входили солдати-земляки 3 різних повітів України. Для координації своєї діяльності вони об'єднувалися у групи з 10-12 чоловік і були постійно діючим органом [13, арк. 2]. На терені ПівденноЗахідного фронту створювалися військові гуртки, клуби, ради та інші організації. Так уже в квітні 1917 р. вони були організовані у XXIV армійському корпусі 9-ї армії, в 155-й Піхотній дивізії 11-ї армії, в гарнізонах Тернополя, Рівного, Житомира.

Уже 12 березня 1917 р. командуючий Південно-Західним фронтом генерал О. Брусилов доповідав воєнному міністру ТУ Росії О.Гучкову про створення фронтового, армійського i корпусного комітетів із залученням до їх роботи військових громадських організацій. У другій половині травня тут уже діяло близько 107 тис. різноманітних солдатських i офіцерських комітетів. Задля контролю над створенням і діяльністю солдатських комітетів, ставка «Тимчасовим положенням по організації чинів діючої армії і флоту» визначила місцем створення комітетів роти, полки, дивізії, корпуси, армії, штаби фронтів.

15 квітня 1917 р. в Кременці зібралися делегати 11-ї армії для обрання армійського комітету. Його головою було обрано більшовика - прапорщика М. Криленка, який відразу почав піднімати питання припинення війни, зменшення ролі офіцерів, саботування рішення ТУ Росії та УЦР. До літа 1917 р. на Південно-Західному фронті до складу комітетів різних рівнів входило більше 75 тис. солдатів.

По містечках і більших селах почали обиратися волосні i сільські виконавчі комітети. В населених пунктах, у яких, або поблизу яких розташовувалися гарнізони та військові підрозділи, під впливом діяльності рад солдатських депутатів, створювалися ради селянських депутатів. При цих радах організовувалися дружини для охорони громадського порядку, захисту інтересів селян.

Загалом територія Західної Волині, на відміну від іiі східних повітів, швидше підпала під вплив більшовицької ідеології, яка починала зароджуватися в солдатських лавах. Базою для більшовицької агітації стали волинські селянські маси, визначальним гаслом для яких залишалося соціально-економічне визволення, насамперед, вирішення земельного питання.

3 іншого боку, десятки організацій, що з'явилися на селі у перші місяці після Лютневої революції, стали на заваді 
консолідації волинського селянства. Більшовицькі агітатори вдало скористалися зволіканням УЦР у вирішенні земельного питання, роздмухуючи ворожнечу до української влади. На фоні цього почастішали випадки переростання протистояння селян $\mathrm{i}$ поміщиків у відкриту боротьбу. Непоодинокими стали грабунки маєтків, підпали господарських споруд та поміщицьких садиб, викрадення худоби і сільськогосподарського реманенту, вирубка панських лісів, захоплення поміщицької землі.

Повітова влада вже не могла стримувати стихійного селянського руху. Не маючи змоги самочинно навести порядок вже існуючими методами, керівники місцевих органів влади намагалися пришвидшити процес створення нових судових органів. Зокрема, Кременецький повітовий комісар звернувся до повітового земельного комітету з пропозицією щонайшвидшого облаштування примирної камери в повіті, яка мала стати своєрідним третейським судом у земельних справах [14, с. 8]. 23 квітня 1917 р. Луцький волосний земельний комітет постановив конфіскувати поміщицьку, монастирську, удільну землі та передати ії безкоштовно селянам. Це рішення, щоправда, не знайшло підтримки у повітового і губернського комітетів [12, с. 76 - 77].

Щоб запобігти поширенню масового захоплення поміщицьких, монастирських i державних земель, Луцька повітова земельна управа прийняла рішення про дозвіл всьому населенню повіту на безкоштовний випас худоби у казенних, церковних, монастирських й приватних лісах, за винятком посадок, вирубок та молодого лісу $[14$, c. 9]. Проте серед членів Луцького повітового земельного комітету це рішення не знайшло підтримки.

Характерною ознакою доби УЦР стала відсутність чіткої концепції військового будівництва держави, а відтак нерозуміння частиною українських політиків ролі війська у тогочасних політичних процесах. Унаслідок цього більшовики отримали широке поле для агітації. Так навесні 1917 р. при штабі Особливої армії в 322-му Обоянському полку, що дислокувався в Луцьку, 47-му Панцерному загоні, який розташовувався в Дубно, 48-му окремому польовому важкому артилерійському дивізіоні, 18-й Ярославській дружині діяли більшовицькі організації [15, с. 6 - 7].

Почастішали випадки, коли військовослужбовці російської армії свідомо йшли на грабунки і погроми, вважаючи, що таким чином вони повертають собі матеріальні блага, недоотримані через війну з вини влади. Так солдати 2-го гусарського ескадрону 
стрілецького полку 2-ї гвардійської кавалерійської дивізії 29 серпня 1917 р. розгромили торгові лавки та магазини м. Ямпіль Кременецького повіту. За повідомленням очевидців, вони по 30-40 осіб заходили до лавок і забирали товар. Наприклад, у магазині Б. Розенберга було забрано галантерейного та бакалійного товару на загальну суму 700 рублів, у магазині І. Гольдфарба на суму 200 рублів, у магазині В. Вайнштейна цигарок, мила, шоколаду, цукерок та фруктів на суму 200 рублів [16, арк. 26 - 27].

Щоразу частіше солдати російської армії відмовлялися виконувати військову присягу, вести бойові дії, зміцнювати оборонні рубежі. Так 12 липня 1917 р. солдати 8-го Туркестанського стрілецького полку відмовилися наступати на Ковель; солдати 501-го стрілецького полку, який розташовувався в Луцьку, відмовилися виступати на бойові позиції проти німецьких бойових частин; солдати 496-й Оргіївського полку, який розташовувався в районі м. Торчин Луцького повіту, відмовилися займати оборону в окопах поблизу їх місця перебування; в районі с. Мерви Дубенського повіту солдати 622-го полку припинили бої та вели переговори з німецькими солдатами.

Більшовицька агітація серед особового складу російської армії наростала впродовж усього літа. На Південно-Західному фронті восени 1917 р. працювали більшовики: М.В.Криленко, Г. І. Чудновський, І. Л. Дзевалтовський, Я. К. Пальвадре, М. М. Коковихін, М. Д. Марченко, Г. В. Разживін [11, с. 35].

Групи РСДРП(б) діяли в Дубні, Луцьку, Олевську, Рівному, Сарнах, Староконстянтинові, інших прифронтових населених пунктах Волинської губернії. В Луцькому гарнізоні більшовицьку агітацію здійснював О. М. Дмитрієв. Більшовицькими за складом стали ради солдатських робітничих і селянських депутатів у Луцьку, в Рожищах, в Коростені і Новограді-Волинському, а невдовзі у Сарнах, Дубровиці, Костополі, Острозі, Староконстянтинові.

У жовтні 1917 р. Волинський губернський комісар А. В'язлов повідомляв про зростання рівня злочинності в повітах губернії, збільшення випадків саботажу й поширення анархії. Звіти комісарів Луцького, Рівненського, Дубенського повітів показували жахливу картину зростання протиправних дій місцевого населення і солдатів Південно-Західного фронту, анархію й дезертирство в російському війську, озлоблення сільських жителів на більш заможних своїх односельців, поширення серед місцевого населення недоброякісного та контрабандного товару. 
Непоодинокими стають випадки, коли місцеві чиновники відмовляються від своїх посад. Так «староста Староконстянтинівського повіту безсилий боротися 3 анархією і просить звільнення» [12, с. 85].

Альтернативою до поширення більшовицької пропаганди в армії повільно, однак поступально стає український рух. Спроби організувати українські військові частини з'явилися на Волині: в Острозі, Житомирі, Рівному [11, с. 95]. На Волині українізація розпочалася у VI армійському корпусі 11-ї армії ПівденноЗахідного фронту. Піхотний полк, який перебував у Житомирі, змінив назву на український полк ім. П. Сагайдачного. Окрім нього, українізаційні процеси охопили VI, XVII, XLI армійські корпуси цього ж фронту.

У вересні - на початку жовтня 1917 р. в багатьох частинах V, VI, XXXI, XXXIV і XLI армійських корпусів Південно-Західного фронту були проведені військові з'їзди солдатів-українців, які вимагали від ТУ Росії українізації війська усіх гарнізонів в Україні, усунення деяких комісарів і командирів.

Не зважаючи невизначеність української політичної верхівки щодо створення власних Збройних Сил, Генеральним Секретаріатом до серпня 1917 р. в загальних рисах було розроблено план українізації армії. Однак відсутність національної концепції військового будівництва, непорозуміння в українському політикумі, нерозуміння частиною членів УЦР ролі армії в політичних процесах дали можливість іншим, насамперед, більшовикам перейняти на себе ідеологічну роботу у солдатському середовищі.

Через гальмування процесу українізації армії та більшовицьку агітацію почали розпадатися щойно створені українські підрозділи. Передислокація військових частин нерідко приводила до їх самоліквідації. Прикладом може слугувати історія, що трапилась 3 українським куренем 102-ї пішої дивізії XXXIX армійського корпусу Осібної армії Південно-Західного фронту [17, с. 6]. Після його відправки $з$ фронту в тил він перестав існувати як бойова одиниця.

Можемо констатувати, що впродовж 1917 p. військовополітична ситуація на волинських теренах суттєво змінювалася в залежності від загальноукраїнських процесів i особливих чинників, притаманних для Волинської губернії. У прифронтових волинських повітах каталізатором змін стала більшовицька 
пропаганда спочатку в солдатському, а згодом у селянському середовищі. Тут з різною інтенсивністю діяли представники ТУ Росії і білышовиків, створюючи свої організації та перешкоджаючи становленню національних органів влади. Окрім того, УЦР не змогла підпорядкувати собі армію колишньої Російської імперії та залучити ії до вирішення державотворчих завдань.

1. Пясеиький В. Перші паростки відродження (Історії Луцької української громади) / В. Пясецький // Краєвид. 2001. - листопад-грудень.

2. Млиновецький Р. Нариси з історії українських визвольних змагань 1917-1918 рр. / Р. Млиновецький. Львів: Каменяр, 1994. - 572 с.

3. Соловйов О. Економічне становище Волині в роки Першої світової війни / О. Соловйов // Науковий вісник ВДУ. Історичні науки. - 1997. - № 2. - С. 35-40.

4. Российский государственный военно-исторический архив (далі - РГВИА), ф. 2067, оп. 1, д. 3792.

5. Литвин C. Військо Центральної Ради: злочинна недбалість чи поріг можливого? [Електронний ресурс] / С. Литвин // Воєнна історія. - 2007. - № 1-3. - Режим доступу до журн. : http: //www. warhistory.ukrlife.org.

6. Верстюк В. Ф. Українська Центральна Рада: навч. посіб. / В. Ф. Верстюк. - К.: Заповіт, 1997. - 344 с.

7. Ковальчук М. А. Лютнева революція 1917 р. в українській провінції / М.А.Ковальчук // Український історичний ж-л. - 2007. - № 4. - С. 91-102.

8. Руднищька $H$. Політичні партії і громадські рухи національних меншин на Волині у 1911-1921 pp./ Н. Рудницька // Шляхами творення Української держави: За м-лами регіон. наук.-практ. конф. «Боротьба українського народу за державну незалежність в 1917-1921 роках». Житомир, 2006. - С. 72-76.

9. Державний архів Волинської області, м. Луцьк (далі - Держархів Волинської обл.), ф. 3, оп. 1, спр. 1614.

10. Косміна P. I. Наш край у 1917-1920 pp. // Наш край в курсі вивчення історії України / Р. І. Косміна, Р.Я. Самостян; упор. С. Ю. Рибчинчук. - Луцьк: Вид-во «Волинська обласна друкарня», 2004. - С. 103-115.

11. Кичий И. В. Борьба за власть Советов на Правобережной Украине / И. В. Кичий. - Львов : Вища школа, 1986. $-152 \mathrm{c}$.

12. Оксенюк Р. Н. Нариси історії Волині. Соціальноекономічний, революційний та національно-визвольний рух трудящих (1861-1939) / Р. Н. Оксенюк. - Львів: Вид-во Львів. ун-ту, 1970. -276 с. 
13. Центральний державний архів вищих органів влади та управління України, м. Київ (ЦДАВО України), ф. 1115, оп. 1, спр. 11.

14. Дем'янюк $О$. Й. Волинська губернія в Українській революції: доба Української Центральної Ради / О. Й. Дем'янюк // Педагогічний пошук. - 2017. - № 2. C. $7-11$.

15. Заболотний I. Нескорена Волинь / I. Заболотний. Львів: Каменяр, 1964. - 204 с.

16. Держархів Волинської обл., ф. 49, оп. 1, спр. 511.

17. Халло Л. Співвідношення військових сил прибічників УНР та їхніх суперників на кінець 1917 - початок 1918 р. / Л. Халло, В. Солдатенко // Історія України. 2001. - № 27 - C. 6 -9.

Надійшла до редколегії 27.01.2018 p.

Рецензент: А.І. Харук, доктор історичних наук, професор, завідувач кафедри гуманітарних наук Національної академії сухопутних військ імені гетьмана Петра Сагайдачного, м. Львів

\section{Demianiuk O. J. \\ VOLYN IN THE PERIOD OF UKRAINIAN CENTRAL COUNCIL: MILITARY-POLITICAL ASPECTS}

The article analyses the military-political peculiarities of the development of Volyn province in the period of the Ukrainian Central Council, in particular, the components of the state-building process at the local level, including the formation of local authorities, the struggle for influence on the Volyn population as well as the activity of various political forces and military formations. The work describes the newly created military committees, councils of workers and soldiers' deputies and also the events, which significantly influenced military-political development of the Volyn lands.

Key words: Ukrainian Revolution, Volyn region, Ukrainian Central Council, military-political situation, military committees, Ukrainian army. 